Biol Neonate 1991;59:I-VI

\title{
Contents, Vol. 59, 1991
}

\section{No. 1 Original Paper}

Development of Urea-Synthesizing Capacity in Preterm Infants during the First Weeks of Life

Boehm, G.; Teichmann, B.; Jung, K 1

Perinatal Hematological Profile of Newborn Infants with Candida Antenatal Infections

Wolach, B.; Bogger-Goren, S.; Whyte, R 5

Modulation of Neonatal Rat Myeloid Kinetics Resulting in Peripheral Neutrophilia by Single Pulse Administration of Rh Granulocyte-Macrophage Colony-Stimulating Factor and Rh Granulocyte Colony-Stimulating Factor

Cairo, M.S.; Ven, C, van de; Mauss, D.; Kommareddy, S.; Norris, K.; Sheikh, K.;

Modanlou, $\mathrm{H} 13$

Developmental Changes in Plasma Apolipoproteins B and A-1 in Fetal Bovines

Marcos, E.; Mazur, A.; Cardot, P.; Coxam, V.; Rayssiguier, Y 22

Ontogeny of Iron Uptake across Brush Border Membrane of Guinea Pig Duodenum and its

Autoradiographic Localisation

Debnam, E.S.; Srai, S.K.S.; Chowrimootoo, G.; Epstein, 030

Detection of Growth-Stimulating Activity in the Proximal Small Intestine during Weaning in the Suckling Rat

Grey, V.L.; Seidman, E.G.; Pham, T.N.; Poullain, M.G.; Morin, C.L

Preferential Utilization of Lactate in Neonatal Dog Brain: In vivo and in vitro Proton

NMR Study

Young, R.S.K.; Petroff, O.A.C.; Chen, B.; Aquila, W.J., Jr.; Gore, J.C 46

Rapid Effects of Hypoxia on the Cerebrospinal Fluid Levels of Adenosine and Related

Metabolites in Newborn and One-Month-Old Piglets

Laudignon, N.; Farri, E.; Beharry, K.; Aranda, J.V 54

Acknowledgement 60

No. 2 Original Paper

Influence of Gestational Age on Potential Difference Across Fetal Type II Alveolar Epithe lium in Alveolar-Like Structures

Orser, B.; Fedorko, L.; Rafii, B.; Post, M.; O’Brodovich, H 61

Fetal Dexamethasone Exposure Affects Basal Ornithine Decarboxylase Activity in Deve loping Rat Brain Regions and Alters Acute Responses to Hypoxia and Maternal Sepa ration

Carlos, R.Q.; Seidler, F.J.; Lappi, S.E.; Slotkin, T.A 69

Lipase and Pepsin Activities in the Stomach Mucosa of the Suckling Dog

Kirk, C.L.; Iverson, S.J.; Hamosh, M 78

Retinal, Choroidal and Total Ocular Blood Flow Response to Hypercarbia during Sponta neous Breathing and Mechanical Ventilation

Stiris, T.; Hall, C; Bratlid, D 86 
IV Contents

Postnatal Development of Mouse Alcohol Dehydrogenases: Agarose Isoelectric Focusing Analyses of the Liver, Kidney, Stomach and Ocular Isozymes

Rout, U.K.; Holmes, R.S 93

Fructose-1,6-Diphosphate, when Given Five Minutes after Injury, Does Not Ameliorate Hypoxic Ischemic Injury to the Central Nervous System in the Newborn Pig

LeBlanc, M.H.; Farias, L.A.; Markov, A.K.; Evans, O.B.; Smith, B.; Smith, E.E.;

Brown, E.G 98

Effects of Chronic Hypoxia during Maturation on the Negative Chronotropic Effect of [H+]

on the Rabbit Sino-Atrial Node

Posner, P.; Baker, S.P.; Epstein, M.L.; Macintosh, B.R.; Buss, D.D 109

Relationships of Serum Estriol, Cortisol and Albumin Concentrations with Pig Weight at

110 Days of Gestation and at Birth

Wisc., T.; Stone, R.T.; Vernon, M.W 114

Announcement 120

No. 3 Original Paper

The High Lectin-Binding Capacity of Human Secretory IgA Protects Nonspeciñcally

Mucosae against Environmental Antigens

Davin, J.-C; Senterre, J.; Mathieu, P.R 121

$\ddot{0} 5 / 8$ Sensitivity in Newborn and Young Infants Tested by the Rebreathing Method.

Methodological Aspects

Katz-Salomon, M.; Hertzberg, T.; Lagercrantz, H 126

Existence of a Digitalis-Like Compound in the Human Fetus

Guédeney, X.; Chanez, C; Scherrmann, J.-M133

Thyroid Function in Fetus and Mother during the Second Half of Normal Pregnancy

Radunovic, N.; Dumez, Y.; Nastic, D.; Mandelbrot, L.; Dommergues, M 139

Physiological Effects of Kangaroo Care in Very Small Preterm Infants

de Leeuw, R.; Colin, E.M.; Dunnebier, E.A.; Mirmiran, M 149

Lack of Influence of Maternal and Fetal Transferrin Phenotypes and Concentrations on

Normal Fetal Growth

Wong, C.T.; Saha, N 156

Cerebral Function of the Guinea Pig Neonate after Chronic Intrauterine Exposure to Khat

\{Catha edulis Forsk.)

Thordstein, M.; Jansson, T.; Kristiansson, B 161

Strain Differences in Mouse Brain Weight Gain and Spatial-Location Scores during Postnatal

Development

Epstein, H.T.; Kaufman, M.; Saperstein, A.; Frank, D.; Huang, S 171

No. 4 Editorial

Regulation of Tissue- and Development-Specific Gene Expression in the Liver

Benvenisty, N.; Reshef, L 181

Original Paper

Clinical and Physiological Responses to Prolonged Nasogastric Administration of Doxapram for Apnea of Prematurity

Tay-Uyboco, J.; Kwiatkowski, K.; Cates, D.B.; Seifert, B.; Hasan, S.U.; Rigatto, H. 190

Molybdenum in the Premature Infant

Bougie, D.; Foucault, D.; Voirin, J.; Bureau, F.; Duhamel, J.F 201 
Contents V

Single Dose of Labetalol in Normotensive Pregnancy: Effects on Maternal Hemodynamics and Uterine and Fetal Flow Velocity Waveforms

Pirhonen, J.P.; Erkkola, R.U.; Mäkinen, J.I.; Ekblad, U.U 204

Plasma Biotin Levels in Neonates

Livaniou, E.; Mantagos, S.; Kakabakos, S.; Pavlou, V.; Evangelatos, G.; Ithakissios, D.S. 209

Lymphocyte Subpopulations in Preterm Infants: High Percentage of Cells Expressing P55

Chain of Interleukin-2 Receptor

Moretta, A.; Valtorta, A.; Chirico, G.; Bozzola, M.; De Amici, M.; Maccario, R. ... 213

Maturation of Respiratory Responses to Graded Hypoxia in Rabbits

Wangsnes, K.M.; Koos, B.J 219

Behavioral Effects of an Intrauterine or Neonatal Diabetic Environment in the Rat

Johansson, B.; Meyerson, B.; Eriksson, UJ 226

Metallothionein in Rat Lung during Postnatal Development

Hart, B.A.; Voss, G.W.; Garvey, J.S 236

Hemodynamic Effects of Conventional and High Frequency Oscillatory Ventilation in

Normal and Septic Piglets

Osiovich, H.C.; Suguihara, C; Goldberg, R.N.; Hehre, D.; Martinez, O.; Bancalari, E. 244

No. 5 Original Paper

Effect of Excess Dietary Fat during Third Trimester of Pregnancy on Maternal, Placental, and Fetal Metabolism in the Pig

Hausman, D.B.; Seerley, R.W.; Martin, R.J 257

Body Composition and Cold Resistance of the Neonatal Pig from European (Large White) and Chinese (Meishan) Breeds

Le Dividich, L; Mormède, P.; Catheline, M.; Caritez, J.C 268

Diet Composition Modifies Embryotoxic Effects Induced by Experimental Diabetes in Rats

Giavini, E.; Broccia, M.L.; Prati, M.; Roversi, G.D 278

Perinatal Glutathione Levels in Liver and Brain of Rats from Large and Small Litters

Glöckner, R.; Kretzschmar, M 287

Glycogen and Enzymes of Glycogen Metabolism in Rat Embryos and Fetal Organs

Gutierrez-Correa, J.; Hod, M.; Passoneau, J.V.; Freinkel, N 294

Effects of Maternal Bilateral Adrenalectomy and Betamethasone Administration on Renal

Rat Encephalic Development

Arahuetes, R.M.; Carretero, V.; Diebold, Y.; Rua, C303

Cathepsin B and D Activities in Intestinal Mucosa during Postnatal Development in Pigs.

Relation to Intestinal Uptake and Transmission of Macromolecules

Ekström, G.M.; Weström, B.R 314

Internal Jugular Venous Oxygen Saturation Does Not Reflect Sagittal Sinus Oxygen Saturation in Piglets

Rudinsky, B.F.; Meadow, W.L

No. 6 Original Paper

Cerebral Blood Flow Velocity Regulation in Preterm Infants

van de Bor, M.; Walther, F.J 329

Neonatal Gastrointestinal Growth and Function: Are They Regulated by Composition of Feeds 
Weaver, L.T.; Landymore-Lim, L.; Lucas, A336

VI Contents

Effect of Maternal Administration of Thyrotropin-Releasing Hormone or DN 1417 on

Functional and Morphologic Fetal Rabbit Lung Maturation and Duration of Survival after Premature Delivery

Devaskar, U.P.; deMello, D.E.; Ackerman, J 346

Apolipoprotein A-I-Containing Lipoproteins in Human Umbilical Cord Blood. Relation to Proapolipoprotein A-I and Lecith $1 / 8$ Cholesterol Acyltransferase

Barkia, A.; Thiemann, E.; Czekelius, P.; Wiegel, A.; Leroy, A.; Fruchart, J.-C; Steinmetz, A 352

Hyperoxemia Does Not Affect Renal Hemodynamics and Function in Newborn Rabbits

Gouyon, J.-B.; Thonney, M.; Guignard, J.-P 358

Size Selectivity of Lung Protein Accumulation in Preterm Ventilated Lambs

Ikegami, M.; Jobe, A.; Tabor, B.; Yamada, T

363

Effect of Blood Transfusion on Acid Base, Glucose and Electrolyte Status in Very Low Birth

Weight Infants

Tan, K.L.; Wong, L.Y373

Abstracts

Abstracts of the 2nd European Workshop on Neonatology

June 20-22, 1991, Klingenthal, France 381

Author Index 399

Subject Index 401 